\title{
CARDOSO DE OLIVEIRA, Luís Roberto. Desvendando evidências simbólicas: compreensão e conteúdo emancipatório da antropologia. Rio de Janeiro: Editora UFRJ, 2018. $272 \mathrm{p}$.
}

Lucas Gonçalves Brito*

*Universidade Federal do Rio Grande do Sul - Porto Alegre, RS, Brasil Doutorando em Antropologia Social (bolsista Capes) lucasgb25@gmail.com https://orcid.org/0000-0002-1639-3721 
Julgar um livro pela capa - ou melhor, comentá-lo pelo título - nem sempre é banal ou superficial. No caso do mais novo livro de Luís Roberto Cardoso de Oliveira, o título, como são os bons, evoca nitidamente a que a obra veio. O termo-chave "compreensão", para além da sua acepção comum, evoca, para toda uma corrente teórica interpretativa, um dos mais caros objetivos da produção do conhecimento. Verstehen, enquanto chave epistemológica que funda os pressupostos filosóficos da hermenêutica, remonta a pensadores da envergadura de Weber, Heidegger e, particularmente para o autor do livro, a Habermas, com quem Cardoso de Oliveira dialogou presencialmente e de quem, talvez, recebeu o influxo intelectual da esperança na ação comunicativa.

Três aspectos conformam os dez ensaios no livro: 1) a relevância analítica prioritária da dimensão simbólica da vida social; 2) as implicações normativas da interpretação antropológica; e 3) a possibilidade de emancipação que a reflexão antropológica engendra, por meio da ampliação do horizonte histórico-cultural tanto de intérpretes quanto de leitores.

Quanto ao primeiro ponto, Cardoso de Oliveira frisa - em diversos trechos e especialmente nos quatro primeiros capítulos e também no décimo - que a característica crucial da antropologia, tal como entende o autor, é decifrar as evidências simbólicas cujo registro é propiciado pelo trabalho etnográfico. Cabe uma citação que conjuga e elucida brilhantemente o ponto:

Embora [a dimensão simbólica] não seja material, trata-se de experiência igualmente empírica e tão concreta quanto o material, sendo passível de apreensão com a mesma objetividade das evidências materiais, mas à qual o antropólogo só pode ter acesso por meio das representações, visões de mundo ou da ideologia (na acepção dumontiana) da sociedade estudada. (p. 23).

Ainda que o(a) leitor(a) possa concordar ou não com a premissa hermenêutica que confere a tônica ao argumento, é imperioso reconhecer que a formulação, lapidada durante anos a fio pelo autor, é de extrema importância para se entender o nível analítico profundo e aparentemente intangível, com o qual, de uma forma ou outra, depara-se cada estudante em antropologia que observa atentamente a questão.

No trecho citado, a pista para as premissas teóricas e epistemológicas de Cardoso de Oliveira torna-se evidente. As linhagens às quais remontam seus 
argumentos estão ali identificáveis: a preocupação durkheimiana com as representações coletivas, a Weltanschauung da sociologia e antropologia compreensivas de Weber e Geertz; e a atenção dumontiana aos sistemas de valores que simbolicamente conformam, de modo bastante concreto, a vida de grupos e sociedades. Uma leitura atenta não se apressará em afirmar que o autor simplesmente aceita que ideias precedem atos ou que alcançar as categorias do entendimento subjacentes aos atos seja todo o processo antropológico. A noção de "pensamento contraintuitivo" previne boa parte das suspeições quanto a idealismos com ou sem sujeito transcendental, os quais, por si mesmos, apenas são problema para disciplinas fortemente voltadas para o empírico, como o são as ciências sociais.

A relevância das ideias para a vida social, que não raro permanece opaca, apenas se revela quando direcionamos nossa atenção ao "mundo da vida" que, nada menos, pode ser entendido como mundo social (cf. p. 10, 22, 147). Se é verdade que o conhecimento antropológico se produz e desvela na dialética entre a observação das relações sociais, tal como vividas, e o deciframento da dimensão simbólica que lhes sustenta, o argumento se situa a um passo da fenomenologia, prima dileta da hermenêutica.

Qualquer antropologia que se preze jamais ignoraria tal questão, uma vez que ela não é exclusiva de uma vertente hermenêutica. Refletir sobre a "vocação crítica da antropologia" (cap. 2) propicia equacionar algumas tensões epistemológicas que, para Cardoso de Oliveira, constituem a disciplina - "a relação dialética entre a ciência e a filosofia, entre a empiria e a metafísica, ou entre o dado e o significado" (p. 40).

Quanto ao segundo ponto, relacionado ao primeiro, o autor ressalta que a antropologia interpretativa se debruça sobre as normas culturais vigentes que orientam a ação social em contextos específicos; e que tais normas estão situadas no âmbito do simbólico. Tais normas se tornam nítidas quando acontece o encontro cultural, através do qual fica à mostra a diferença das ações das pessoas inseridas em diferentes contextos culturais.

A preocupação com o aspecto normativo da ação social, isto é, as regras específicas compartilhadas coletivamente, parece, ao menos em parte, provir do engajamento analítico do autor com a antropologia jurídica, cuja operação conceitual básica oscila entre normativismos e processualismos (ver p. 91). Para além dos dilemas epistemológicos na compreensão dos diferentes universos 
jurídicos/legais, a questão da adequação normativa também está imbricada na perspectiva comparativa que acompanha o fazer antropológico (cap. 6), cujo procedimento básico não raro tem sido a escolha de objetos de comparação que são, em termos metodológicos, tipos ideais e unidades exemplares de contextos etnográficos e/ou sociológicos particulares.

Cabe notar que, dentre as linhas que amarram os textos, pode-se apontar a aparente dissonância do capítulo 9 em relação ao tom geral do livro. Trata-se de uma análise estrutural à maneira levistraussiana da lógica do mito krahô do Velho Cego, o qual Cardoso de Oliveira assevera dizer respeito à visão nativa do contato interétnico. Contudo, a dissonância teórica aparente se dissipa quando quem lê percebe, em certos pontos ao longo do livro, que as reflexões do autor foram influenciadas não só pelas diversas correntes hermenêuticas, mas também pelo estruturalismo, tal como entendido por Lévi-Strauss (1975) e Dumont (1993). Ademais, a questão dos símbolos, ainda que se conceba distintamente o que vem a sê-lo, é inerente às duas linhagens. Apenas pensadores de envergadura conseguem navegar com certa segurança por diferentes correntezas teóricas sem perder o rumo. E isso, se minha leitura estiver correta, demonstra a importância do que eu chamaria de reflexão metateórica enquanto outro elemento fundante da vocação crítica da disciplina.

O último capítulo remete exatamente a essa reflexividade teórica presente nas formulações de Cardoso de Oliveira. Para o autor, sua trajetória intelectual foi influenciada pela preocupação analítica com a dimensão simbólica, a dimensão empírica e o contraintuitivo (que são desafios apresentados já no primeiro capítulo). A noção de contraintuitivo está também no cerne do entendimento do autor quanto ao trabalho antropológico como produção de conhecimento científico acerca do mundo social. Ao contrário da filosofia, conforme Cardoso de Oliveira, as ciências sociais enfatizam os "aspectos da experiência humana apreendidos por meio da observação empírica, independentemente das intuições dos atores, e frequentemente expressos naquilo que se convencionou chamar de evidências materiais" (p. 195). Esse trecho talvez conjugue as conceptualizações que o autor pôde construir através de seus anos de pesquisas, e demonstra as saídas que ele encontrou no surpreendente labirinto antropológico.

Para encerrar este sucinto círculo hermenêutico, voltemos ao início, à capa do livro. O Homem vitruviano, em miniatura e pela metade, incrustado na letra 
"O" da primeira palavra do título, convida a desvendar as pistas simbólicas que caberá à antropologia interpretativa, por meio da análise, evidenciar. E não seria exagero sugerir que a outra metade do humano, na boa tradição humanista, somente se completará na fusão do horizonte cultural das diferenças entre pessoas, porque o humano apenas se completa nas infinitas alteridades possíveis do ser humano no mundo.

\section{Referências}

DUMONT, L. O individualismo: uma perspectiva antropológica da ideologia moderna. Rio de Janeiro: Rocco, 1993.

LÉVI-STRAUSS, C. Antropologia estrutural. Rio de Janeiro: Tempo Brasileiro, 1975. 